\title{
Posture Verbs in Two Tibeto-Burman Languages of Nepal ${ }^{1}$ \\ Michael Noonan \& Karen Grunow-Hårsta University of Wisconsin-Milwaukee
}

0 . Introduction: In this paper we will examine the syntax and semantics of expressions which, either currently or historically, contain verbal expressions denoting posture ['stand', 'sit', 'lie'] in two Tibeto-Burman languages of Nepal: Chantyal [TibetoBurman: Bodic: Bodish: Tibetic: Tamangic] and Magar [Tibeto-Burman: Bodic: Himalayish: Kham-Magar]. The genetic relationship of these languages to each other and to other members of the Bodic Division of Tibeto-Burman is outlined in Figure 1.

\section{Posture verbs in Chantyal}

1.0 Introduction: The Chantyal language is spoken by approximately 2000 of the 11 ,000 ethnic Chantyal. ${ }^{2}$ The Chantyal live in the Baglung and Myagdi Districts of Nepal; the villages where the Chantyal language is spoken are all located in the eastern portion of the Myagdi District and include the villages of Mangale Khāni, Dwāri, Ghyã̃s Kharkā, Caura Khāni, Kuine Khāni, Thārā Khāni, Pātle Kharkā, Mālāmpāhār, and Malkābāng. There is relatively little linguistic variation among these villages, though where differences exist, it is the speech of Mangale Khāni that is represented here.

The Chantyal language is a member of the Tamangic group and, within the group, it is lexically and grammatically closest to the Thakali Complex. Assessment of the internal relations within the group is complicated by a number of factors, among which is the fact that shared innovations may be the product of geographic contiguity as much as shared genetic background. At the moment, the most likely classification is as follows:

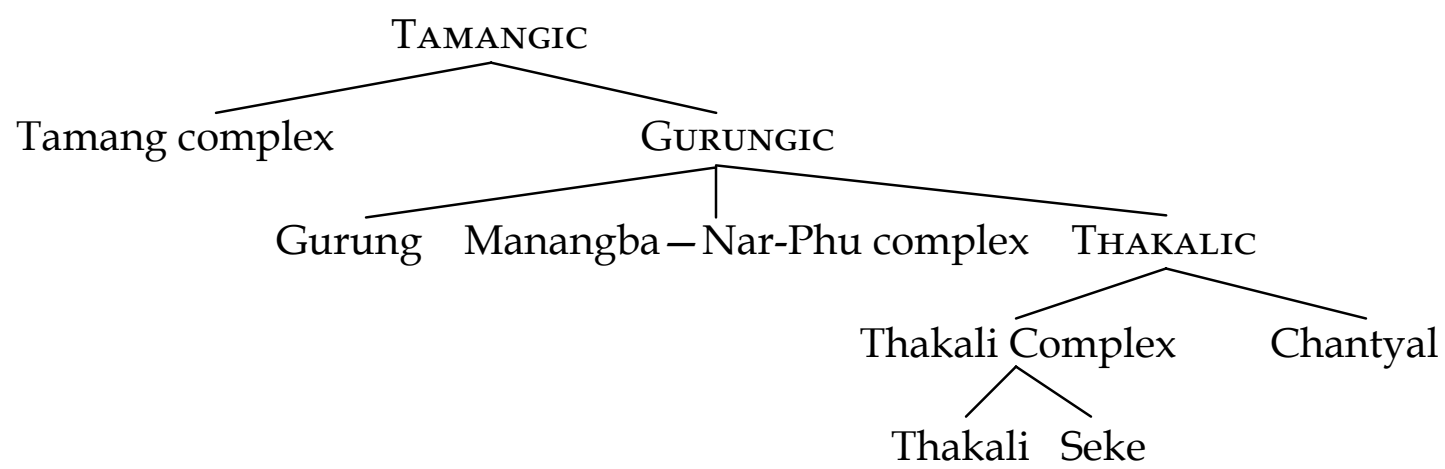

Chantyal, however, is in many respects the most deviant member of the group, lacking a tone system and having borrowed a large portion of its lexicon from Nepali. In addition, there appears to be a layer of Tibeto-Burman vocabulary that is not Tamangic.

The Chantyal were traditionally identified as Magars [most printed references refer to them as 'Chantel Magars'], but this identification was based on a deliberate misrepresentation fostered by the Chantyal for various practical reasons. ${ }^{3}$ In fact, Chantyal and Magar are not especially close genetically, as shown in Figure 1, but they have been in contact for at least two centuries and their grammars have been converging, both 
through influence of Magar on Chantyal and through influence of Nepali on both (Noonan 2001b).

1.1 Posture expressions in Chantyal: In this section we will discuss a set of basic expressions denoting posture in Chantyal. By 'basic expression', we mean expressions whose meanings contain the minimum reference to manner available in the language for the expression of a particular posture.

Basic expressions denoting posture in Chantyal consist of a few simplex verbs and set of complex expressions. The complex expressions contain an orientational word and one of a set of generic verbs translating English 'do', 'become', and 'happen'.

Expressions denoting standing include the simplex verbs in (1) and the complex expressions in (2):

(1) yep-

yes-

(2) tharo la-

tharo ta-

tharo pəri- 'maintain a standing position'

'assume a standing position'

'maintain a vertical position' [literally: 'vertical do']

'assume a vertical position' [literally: 'vertical become']

'come to be in a vertical position' [literally: 'vertical happen']

The verbs in (1) refer to muscular activity; they cannot be used with inanimate subjects. The expressions in (2), on the other hand, refer to vertical position and can be used with inanimate subjects also, though see below for more discussion of this.

There is only one basic expression denoting sitting, and it consists of a simplex verb:4

ci-

'sit'

On the other hand, there are no basic expressions denoting lying consisting only of a simplex verb. All basic expressions referring to lying are complex:

(4) terso la-

terso ta-

terso pəri-

(5) wattano lawattano tawattano pəri- 'maintain a horizontal position' [literally: 'horizontal /flat do'] 'assume a horizontal position' [literally: 'horizontal/flat become']

'come to be in a horizontal position' [literally: 'horizontal /flat happen']

'maintain a supine position' [literally: 'supine do'] 'assume a supine position' [literally: 'supine become'] 'come to be in a supine position' [literally: 'supine happen'] 'lie down' [literally: 'ground-Loc rest.on']

\section{(6) bfũy-ri than-}

The difference between the sets of complex expressions in (4) and (5) rests on the differences in meaning of terso 'horizontal, flat' and wattano 'supine [face up]'. The latter, since wattano makes crucial reference to the face, can only be used with regard to humans and animals; the former, however, can be [and is] used with reference to people and can also be used with inanimates. The expression in (6) includes the verb than-, which means literally 'hang on, rest on', implying that the subject is being supported or held up by something. ${ }^{5}$ 
In sum, Chantyal makes extensive use of complex expressions in referring to posture. And, as we have seen, there is no simplex verb denoting the lying posture in the language. There is a simplex verb for sitting, however, and no corresponding complex expressions with only this basic meaning. Expressions for standing consist of both simplex verbs and complex expressions.

This distribution of simplex and complex expressions is consistent with predictions from Givón's (1984) time-stability continuum and Hopper \& Thompson's (1980) transitivity continuum: lying, the least agentive and therefore least transitive of the basic posture expressions is the least prototypically verb-like and therefore the one most likely to receive complex expression involving a stative positional word.

1.2 The syntax of posture expressions: Chantyal is a consistently ergative language, which is to say that transitive subjects are in the ergative case, marked by the case clitic -sə, but intransitive subjects are in the absolutive case, which is unmarked. Direct objects are either absolutive or dative, the latter if their animacy is relevant to the meaning of the clause. ${ }^{6}$

The basic posture expressions described in the last section are all intransitive, and thus have absolutive subjects. Examples follow: ${ }^{7}$

(7) Pirəm thim-muwari yep-ji

Piram house-ADEs stand-PERF

'Piram stood near the house.'

mhun-cho nə yewta kalce bənnu tharo la-siro

night-LOC FOCUs one black gun vertical do-SEQ

'at night a black gun stood erect, and.' [R78]

(9) Ram kurci-phyaray ci-i

Ram chair-SUPER Sit-PERF

'Ram sat on the chair.'

(10) Om bhüy-ri terso ta-i

Om ground-LOC horizontal become-PERF

'Om lay on the ground.'

(11) Om bhũy-ri than-ji

Om ground-LOC hang-PERF

'Om lay on the ground.'

There are no simplex verbs denoting transitive or causative counterparts of the basic expressions; that is, there are no simplex verbs with meanings analogous to English 'stand smth up', 'set' ['place in a sitting position'], or 'lay' ['place in a lying position']. Causative counterparts can be formed, however, by either of two methods for making causative contructions in Chantyal. For native verbs, causative contructions are formed by placing the resultative suffix -nə on the semantic main verb and adding the auxiliary verb la- 'do':

(12) Ram-sə nãni-ra yep-nə la-i

Ram-ERG baby-DAT stand-RSLT do-PERF 
'Ram stood the baby up.' [i.e. caused the baby to stand] Note that this sentence has the expected ergative subject and dative-marked direct object.

Chantyal has borrowed a very large portion of its lexicon from Nepali, and verbs borrowed from Nepali often are found in intransitive/transitive pairs, unlike verbs in the native portion of the lexicon. The morphological marking for transitivity is based on the Nepali originals, but is manifested somewhat differently and in a rather simpler system than one finds in Nepali. As it happens, only one of the verbs in the set of basic posture expressions is borrowed from Nepali: pəri- 'happen', which has a transitive counterpart pari- 'cause to happen'.

(13) Om-sə nãni-ra terso pari-i

Om-ERG baby-DAT horizontal make.happen-PERF

'Om lay the baby down.' [i.e. caused the baby to become horizontal]

\subsection{The semantics of posture expressions:}

1.3.1 Auxiliaries: In Section 1.1, a set of basic expressions for referring to posture was presented. While there was only one [simplex] expression for sitting, for standing and lying there were a number of periphrastic expressions formed with a set of three auxiliary verbs, la- 'do', ta- 'become', and pəri- 'happen'.

la- 'do' is an active proverb which can substitute for any active verb, transitive or intransitive. It implies activity, so in (14)
(14)
Ram tharo la-i
Ram vertical do-PERF
'Ram stood.'

we assume that Ram actively maintained a standing position. When it is used with inanimate subjects, as in (8), repeated below,
mhun-cho no yewta kalce bənnu tharo la-siro
night-LOC FOCUS one black gun vertical do-SEQ
'at night a black gun stood erect, and.' [R78]

the subject is presented as a volitional actor: in the story from which (8) is taken, the gun is standing before the narrator in a dream.

ta- 'become' is an active copular verb, implying a transition from one state to another. Its subjects may be animate or inanimate.

(15) dolin terso ta-si-m

house.beam horizontal become-ANT-NPST

'The housebeam lay horizontally.'

pəri- has a complex set of meanings in Chantyal and also in Nepali, from which the word was borrowed. The original sense in Nepali is 'fall'; in Chantyal, the basic sense is 'happen'. In posture expressions, it contributes the sense that the state of affairs thus described is the result of an event or events mentioned or alluded to earlier. Like ta- 'become', its subjects may be animate or inanimate.

(16) dolin ajoy terso pəri-m

house.beam still horizontal happen-NPST 
'The housebeam is still horizontal.' [i.e. still hasn't been raised]

The contributions of these auxiliary verbs to posture expressions are summed up in (17):

(17)

\begin{tabular}{|l|l|}
\hline la- & implies activity on the part of the subject; animate subjects only \\
\hline ta- & $\begin{array}{l}\text { active copular verb; implies transition between states; animate or } \\
\text { inanimate subjects }\end{array}$ \\
\hline pəri- & resultant state; animate of inanimate subjects \\
\hline
\end{tabular}

These verbs are found in many other expressions; the orientational words associated with the verbs in (17) supply the meanings for the sense of posture expressions: tharo 'vertical', terso 'horizontal, flat', and wattano 'supine'.

1.3.2 Agency \& movement: Expressions denoting posture in Chantyal are divided between those which attribute agency to the subject and those which do not. For standing, the simplex verbs yep- 'maintain a standing position' and yes- 'assume a standing position' require an agent subject, as does the complex expression tharo la- 'maintain a vertical position'. tharo ta- 'assume a vertical position' and tharo pəri- 'come to be in a vertical position', as noted earlier, do not require an agent subject. The basic expression for sitting, ci- 'sit', requires an agent subject. Of the expressions for lying, all of which are complex, those formed with la- 'do' require an agent subject and the rest do not.

In this way, Chantyal distinguishes between expressions which denote an active involvement on the part of the subject in the assumption or maintenance of a particular posture and those which simply express a specific vertical-horizontal orientation, the latter being available for animate or inanimate entities. For animate subjects, therefore, the speaker has a choice between framing the utterance so as to emphasize the subject's active involvement or framing it so as to background or even deny active involvement.

Another distinction which the Chantyal speaker must make in referring to posture is the distinction between the subject's assuming and maintaining a given posture. Expressions denoting standing and lying are so divided between those implying motion and those that do not, but ci- 'sit' is neutral in this regard, and in this way is like the English verb sit, which can also be used to refer to assuming or maintaining a sitting position.

Expressions for standing and lying can be displayed relative to the agency and motion as in (18): 


\begin{tabular}{|c|c|c|c|}
\hline EXPRESSION & $\begin{array}{l}\text { STANDING/ } \\
\text { LYING }\end{array}$ & $\begin{array}{l}\text { AGENT } \\
\text { SUBJECT }\end{array}$ & $\begin{array}{l}\text { ASSUMING / } \\
\text { MAINTAINING POSITION }\end{array}$ \\
\hline yep- & standing & yes & maintaining [non-notional] \\
\hline yes- & standing & yes & assuming [motional] \\
\hline tharo la- & standing & yes & maintaining [non-motional] \\
\hline tharo ta- & standing & no & assuming [motional] \\
\hline tharo pəri- & standing & no & assuming [motional] \\
\hline terso la- & lying & yes & maintaining [non-motional] \\
\hline terso ta- & lying & no & assuming [motional] \\
\hline terso pəri- & lying & no & assuming [motional] \\
\hline wattano la- & lying & yes & maintaining [non-motional] \\
\hline wattano ta- & lying & no & assuming [motional] \\
\hline wattano pəri- & lying & no & assuming [motional] \\
\hline bfũy-ri than- & lying & no & maintaining [non-motional] \\
\hline
\end{tabular}

It should be noted in passing that Chantyal has a set of motion verbs whose sense includes an invited inference that a lying or standing posture is achieved as a consequence of the motion, but which do not encode the posture directly or include the achieve of the posture as an entailment. For example, the verb khur- means 'fall' or 'trip' and invites an inference that the subject is horizontally positioned, i.e. terso, as a result. The meaning does not entail this posture, however.

1.3.3 Expression of location: Posture expressions in Chantyal are not used idiomatically to express location. One does not find in Chantyal, therefore, idiomatic expressions analogous to the following English sentences:

(19) The house stood on the edge of a cliff.

The book sat on the table.

The pieces lay on the floor.

In translating all of the above, a Chantyal speaker would use a simple locative expression involving a copular verb:

phara-ye tawko-ri thim mu-õ

mountain-GEN edge-LOC house be-IMPF

'The house was/stood on the edge of a cliff.'

Indeed, posture expressions are used with inanimates mostly when a vertical or horizontal orientation is somehow basic to their definitions, the sorts of mental scenes they invoke. So, a posture expression might appropriately have as a subject a housebeam or a tree, but not a watch or a book. And even then, it is only expressions denoting vertical or horizontal position, standing and lying, which are potentially available for inanimates: the only dedicated basic expression for sitting, ci-, can be used only with animates and only those for which reference to a sitting posture would make sense. 
1.3.4 Expression of manner: Chantyal lacks simplex expressions which lexicalize posture + manner in verbs analogous to English 'squat', 'crouch', 'lean', and so on. Such expressions are always complex in Chantyal involving either an orientational word

(21) ghowto pəri-wa

prone happen-NOM

'lean over, bend over, lie face down.'

or an item in the 'expressive vocabulary' (Noonan 2001a):

kyata dhutummo ci-i

boy sitting.upright sit-PERF

'The boy sat upright.'

kyata cakre-makre la-si ci-i

boy sit.cross.legged do-ANT sit-PERF

'The boy sat cross legged.'

The lack of simplex verbs encoding posture + manner is consistent with the way the expression of manner is handled generally in the language: manner is most frequently encoded by expressive vocabulary, often with la- 'do' functioning as an anterior converb, as illustrated by (22)-(23) above.

1.3.5 Polysemy of basic posture expressions: At various points in the preceding paragraphs we have noted ways in which the meanings of the basic posture expressions either overlap with other posture expressions or have sense that extend beyond the expression of posture. For example, the posture expressions containing tharo 'vertical', repeated below, are used to expressing standing: they can also be used to express sitting, especially in reference to the assumption of a sitting posture from a lying position:

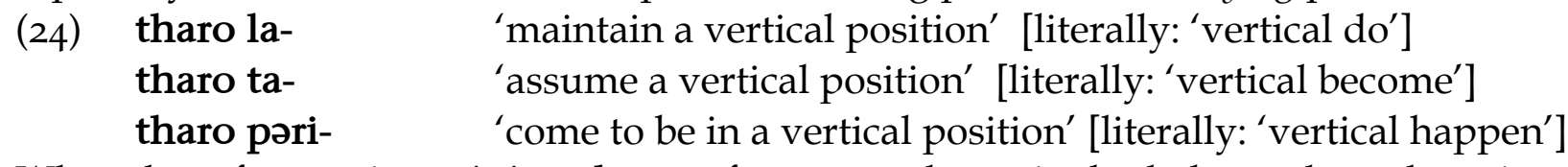

When the reference is to sitting, tharo refers not to the entire body but only to the spine. All of the complex expressions can be used to encode a set of meanings based on a literal interpretation of their components.

Of the simplex verbs, ci- 'sit' is the only one to have extended its meaning much beyond the expression of a basic posture sense. ci- has acquired a range of meanings, including: sit, live [somewhere], be in a place, stay, remain, wait; continue; be [a member of a profession]; seem. A few examples of these additional senses follow:

yəwta gãw-ri yəwta bura ci-ma

one village-Loc one old.man sit-IMPF

'There was an old man who lived in a village.' [P1]

nhi Ram-ye yəwta them-əy ci-i

we Ram-GEN one house-LOC sit-PERF

'We stayed in one of Ram's houses.'

(27) shya-i ci-m

look-ANT sit-NPST

'He's staring.' 
cater nә khi nә mastər ci-wa pəri-m bhi-i

then FOCUS you FOCUS teacher sit-NOM happen-NPST say-PERF

"'You have to be the teacher," they said from that time on.' [U103-4]

mãya khi-ye honuwar lü-i ci-si-m

love you-GEN appearance shine-ANT sit-ANT-NPST

'[My] love, your appearance seems to shine.' [AA82]

1.4 Grammaticalization of posture expressions: In the last section it was noted that ci'sit' had evolved a range of meanings, a few of which were illustrated in (25-9). We assume that the 'sit' meaning is an old one, and that the others derive from that sense by means of meaning extensions familiar from the histories of many languages. The 'seem' and 'be [in a profession]' senses are copular, extensions arising ultimately from the stative, durative senses of 'sit':

(30) $\quad$ SIT $\rightarrow$ STAY $\rightarrow$ REMAIN $\rightarrow$ BE/SEEM

The 'continue' sense has a similar semantic origin, but with a somewhat different grammatical result, since here ci- assumes the status of an auxiliary:

(31) kha la-i ca-wa ci-m-ẽ cu raches-sə

how do-ANT eat-NOM sit-NPST-Q this ogre-ERG

'How does he continue to eat them, this ogre?' [AA90]

There is evidence that the copular verb mu derives historically from a verb meaning 'sit, stay'. In Chantyal, mu is used for the expression of location and attribution; another stative coplua, hin, is used for identification. ${ }^{8}$ The locational sense in particular is expected in a copula deriving from a verb with a 'sit, stay' sense. Forms clearly cognate with $\mathbf{m u}$ are widespread in copular function in the Bodic Division of Tibeto-Burman. Where they have a meaning that is not simply copular, they mean 'sit, stay', as in Magar [see below].

The mu copula has developed into an auxiliary verb and a non-past suffix on verbs. In the latter function, it is suffixed directly to the verbal stem. It has two allomorphs, $-\mathbf{m}$ and $-\mathbf{m u}$, the latter appearing in certain phonologically conditioned environments and optionally [but rarely] elsewhere.

(32) na-sə sar-mu

I-ERG kill-NPST

'I'1l kill it.' [P37]

(33) omrika-ne-ma-thõy la-si-ro ci-m

America-PERSON-PL-ESS do-ANT-SEQ sit-NPST

'He sits down like an American.'

(34) khi nə bipotta ta-si-m

you focus terrible.state become-ANT-NPST

'You're in a terrible state.' [L24]

As an auxiliary, $\mathbf{m u}$ is found in a number of constructions involving predictive, progressive, and resultative senses. A few examples follow:

(35) na kam-ri tho-wa-bhonda pəyle, Ram kam la-wa mu 
I work-LOC arrive-NOM-COMP before Ram work do-NOM be.NPST 'Even before I get to work, Ram will be working.'

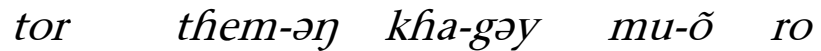

upward house-LOC bring-PROG be-IMPF REPORT

'[It was said that] he was bringing them up to the village.' [M5]

(37)

yi-sər-wa sãra-si-wa mu-õ $n u$

this-manner-NOM swell-ANT-NOM be-IMPF REMINDER

'It had swollen like this.' [I85]

(38) cə din nә bənnu nә bhərə-ysi-wa mu-wa hin-si-m

that day Focus gun FOCUS fill-ANT-NOM be-NOM be-ANT-NPST

'That day, it turned out that the gun was loaded.' [R20]

The sense contributed by $\mathbf{m u}$ in such constructions, historically, was stativity and location within the time of an event.

\section{Posture verbs in Magar}

2.0 Introduction: According to the 1991 census of Nepal, there were 1,339,308 ethnic Magars, of whom only 430,264 (32.1\%) spoke their ancestral tongue. ${ }^{9}$ Magar speakers can be found throughout central and west-central Nepal, but they are the dominant ethnic group in several districts: Rolpa, Pyutan, Baglung, Myagdi, Palpa, and Tanahu. Significant populations exist also in the Syangja and Kaski districts. The identification of Magars is complicated by the fact that a number of other ethnic groups, some speaking languages completely unrelated to Magar, have claimed to be Magars to outsiders. These groups include the Chantyal [as noted above], the Kham, the Kaike, the Kusunda, the Raute, and the Raji. ${ }^{10}$

While the Magar dialects listed in Figure 1 form a linguistic group and are clearly more closely related to each other than to any language outside their group, there is considerable linguistic diversity among them, even to the point where the dialects differ in the presence or absence of a few major features defining different typological classes of languages in Nepal (Noonan 200ob). ${ }^{11}$ The dialects considered in this paper fall into two groups:

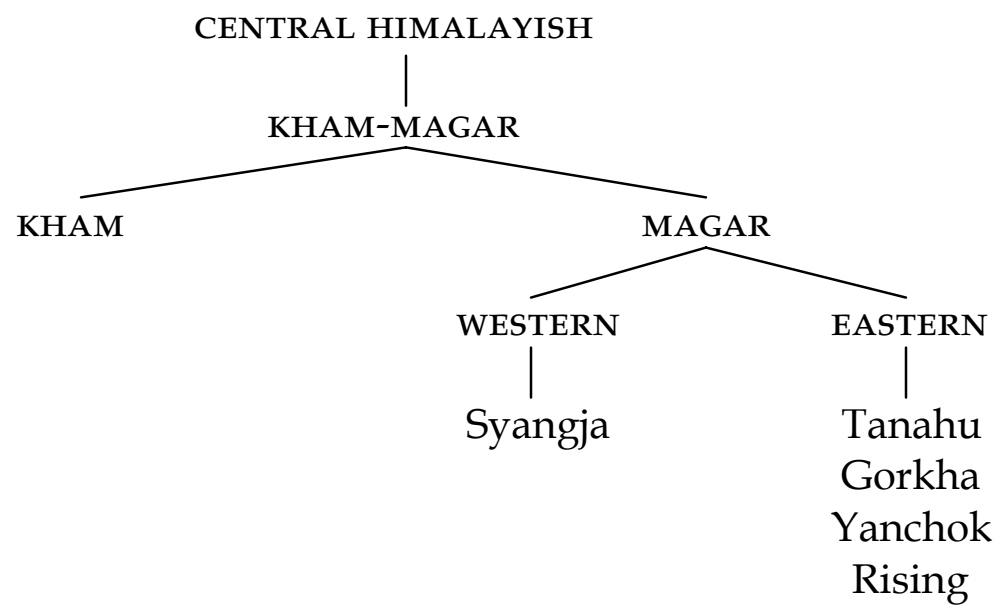


All of the Magar dialects have been influenced to one degree or another by IndoEuropean Nepali, the national language. The eastern dialects, Tanahu and Gorkha in particular, have innovated considerably in the direction of Nepali, whereas, Syangja has preserved more conservative features. The source dialect is indicated in the examples below. ${ }^{12}$

2.1 Posture expressions in Magar: The Chantyal and Magar languages, though they are related and may have been spoken in close proximity at various times in their histories, ${ }^{13}$ are very different in their treatment of posture expressions. In section 1.1, we saw that Chantyal makes extensive use of complex expressions in referring to posture, having only a small set of simplex verbs with posture senses. In Magar, on the other hand, there are verbal roots with meanings referring either directly to posture or to motion up or down [rising or falling] which, in combination with a set of voice/transitivity [VT] suffixes, produce verbal stems which can be used to denote posture.

In general, the system works as follows: ${ }^{14}$ each verbal root forms at least two stems, one of which is causative. The other stem contains one of the other VT suffixes [transitive, intransitive, or middle] or is unmarked. The causative is formed:

$\begin{array}{ll}\text { CAUSATIVE } & -(\mathbf{V}) \mathbf{k}- \\ \text { TRANSITIVE } & -(\mathbf{V}) \mathbf{t}- \\ \text { INSTRANSITIVE } & -(\mathbf{V}) \mathbf{s}- \\ \text { MIDDLE } & -(\mathbf{V}) \mathbf{h}-{ }^{15} \\ \text { UNMARKED } & -\varnothing-\end{array}$

The unmarked form can be transitive or intransitive in sense. No verbal root has all five theoretically possible stems. A few roots have four; many have three.

Verbal stems denoting sitting include the following:

MIDDLE UNMARKED INTRANS. TRANSITIVE

mu-

ba-h'sit, stay' 'settle down, 'sit' ba-sba-t'set down' alight'

Verbal stems denoting standing include the following set:

$\begin{array}{lll}\text { (41) } & \text { MIDDLE } & \text { UNMARKED } \\ \text { so-h- } & \text { INTRANS. } \\ & \text { 'swell up' } & \text { 'stand, rise, } \\ & & \text { wake' }\end{array}$

ton-h-

$\begin{array}{ll}\text { TRANSITIVE } & \text { CAUSATIVE } \\ \text { so-t- } & \text { so- } \mathbf{h}-\mathbf{a k} \\ \text { 'stand smth, } & \text { 'cause to swell' } \\ \text { raise, } & \text { so-k } \\ \text { awaken' } & \text { 'cause to rise/wake' } \\ & \text { so-t-ak } \\ & \text { 'cause to raise/awaken' } \\ & \text { ton-h-ok }\end{array}$


'be in a standing

position; stop, wait' 'cause to stand/stop/wait'

\section{thor-os}

'stand, rise' thor-os-ak

'cause to stand/rise'

Magar, like Chantyal, has no basic expression for lying, nor any complex expression whose only or basic sense is 'lie'. What we find instead, as indicated in (42), are verbs whose basic sense is 'flop down, collapse' or 'fall'. None of these denotes simply the basic posture of lying; rather, these verbs describe an event which could result in the subject assuming a lying posture. The assumption of a lying posture is not stated directly, but left to inference.

$\begin{array}{lll}\text { (42) } \begin{array}{l}\text { MIDDLE } \\ \text { pol-oh- } \\ \text { 'flop down, } \\ \text { collapse, lie down' }\end{array} & \begin{array}{l}\text { TRANSITIVE } \\ \text { pol-ot- } \\ \text { 'put or lay } \\ \text { down' }\end{array} & \begin{array}{l}\text { CAUSATIVE } \\ \text { pol-h-ok }\end{array} \\ \begin{array}{l}\text { 'cause to fall down/ } \\ \text { collapse/lie; roll over' } \\ \text { pol-ot-ak- }\end{array} \\ \begin{array}{l}\text { khor-h- } \\ \text { 'fause to put/lay down' } \\ \text { khor-h-ok }\end{array} \\ \text { 'cause to fall/lie' }\end{array}$

The state of being in a lying posture is expressed with a construction containing a nominalization of one of these verbs together with a resultative or stative auxiliary itself derive from the posture verb mu- 'sit' which in this construction functioning as a resultative auxiliary [section 2.3.5].

(43) khor-h-mə $\mathrm{mu}$ -

fall-MID-NOM sit

'be in a lying posture.'

In sum, we see that Magar, like Chantyal, maintains a distinction between expressions denoting standing and sitting, on the one hand, and lying on the other. In both languages, there are expressions for standing and sitting involving simplex verbs with primary senses denoting their respective postures. Expressions denoting lying, on the other hand, involve either complex expressions or simplex verbs referring to the lying posture only indirectly by inference.

2.2 The syntax of posture expressions: Magar is a morphologically ergative language. The dialects differ in that some are consistently ergative, like Chantyal, and some display split ergativity on the Nepali model. The western dialects, represented here by Syangja, are consistently ergative. The eastern dialects [Tanahu, Gorkha, Rising, and Yanchok] have an aspect-based split ergativity wherein perfective aspect correlates with ergative syntax and imperfective clauses with accusative syntax. The absolute case is unmarked; the ergative is marked with the suffix $-\mathbf{i} / \mathbf{e}$.

In the western dialects, and in the eastern dialects in the perfective aspect, the absolutive is found with subjects of intransitive and middle stems, and the ergative is found with subjects of causative and transitive verbal stems:

MIDDLE 
(44) Gandaki-ay mudha pol-oh-a

river-LOC $\log$ fell-MID-PST

'the log lay/fell in the river.'

INTRANSITIVE

(45) Sita tebəl-ay ba-s-a

Sita table-LOC stood-INTR-PST

'Sita stood on the table.'

TRANSITIVE

(46) Manas-e biruwa jha- $\eta$ so-t-a

Manas-ERG sapling ground-LOC stood-TR-PAST

'Manas stood sapling on the ground.'

CAUSATIVE

(47) Bhim-e mi-ja-ke ba-s-ak-a

Bhim-ERG POSS-child-DAT sit-INTR-CAUS-PST

'Bhim made the child sit down.'

With posture verbs, unmarked verbal stems are always intransitive and thus have absolutive subjects:

(48) Shrigana im-ay mu-a

Shrigana house-LOC sit-PST

'Shrigana sat in the house.'

(49) babu-ja galam-ay so-a

boy-child door-LOC stand-PST

'the boy stood at the door.'

The intransitivity of these verbs reflects the Aktionsart of these verbal roots: some unmarked verb stems are grammatically transitive.

Magar, like Chantyal, exhibits the anti-dative phenomenon, whereby direct objects high in animacy are marked in the dative case; other direct objects are absolutive, which is to say morphologically unmarked. (47) illustrates the marking of animate direct objects. In (50), we have an example of a causative of a transitive, which shows that the subordinated agent is rendered in the dative case:

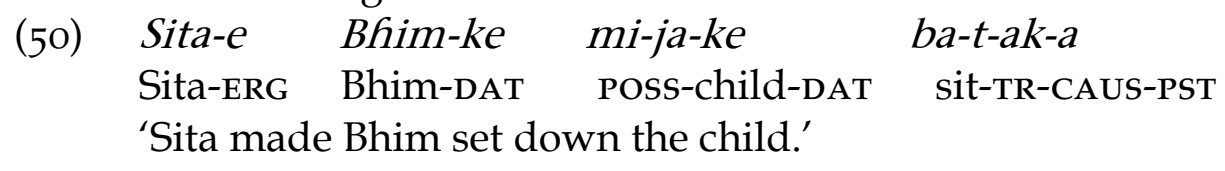

\subsection{The semantics of posture expressions:}

2.3.1 Transitivity and voice: We had earlier discussed how, in referring to posture, Chantyal speakers must, on the one hand, distinguish between expressions which attribute agency to the subject and those which do not; and, on the other hand, distinguish between those which denote the assumption of a given posture and those which denote the maintenance of one. Neither of these distinctions, so fundamental to the Chantyal mode of referring to posture, is encoded syntactically or morphologically in Magar. 
However, as noted, Magar employs an elaborated system of voice and transitivity marking that has no analog in Chantyal. At one stage in the history of Magar, this system must have been fully productive. Benedict (1972) reconstructs* $\mathbf{t}$ and *s stemfinals for Proto-Tibeto-Burman with meanings - directive/causative and reflexive/middle, respectively - that show that the Magar system is a direct continuation of a Proto-TB transitivity marking system. At this stage in the history of the language, however, only the causative is fully productive: every verbal stem [transitive, intransitive, middle, or unmarked] has a causative counterpart, as (40)-(42) attest. However, the distribution of the other verbal stem-types indicates that these forms are fully lexicalized and are not derived by morphological processes. From a purely synchronic perspective, it is not possible to predict for these posture expressions why certain theoretically possible VT stems are not found. So, for example, for verb roots referring to sitting, we have only an unmarked form for $\mathbf{m u}$-, along with the inevitable causative, while for ba-, we have a middle, an intransitive, and a transitive [and corresponding causatives], but no unmarked form. Unmarked $\mathbf{m u}$ - and morphologically intransitive ba-s- are more-or-less synonymous. For standing, we have morphologically unmarked so- paired with transitive so-t-, alongside an unpaired, morphologically intransitive thor-os- and a middle [and unpaired] ton- $\mathbf{h}$-. While we could not predict from the meanings of the verbal roots how the stem forms would be distributed among them, it is nonetheless remarkable that, with the predictable exception of the causatives, we have for both sitting and standing full paradigms of verbal stems distributed among the various roots. So, for sitting, we have

$\begin{array}{llll}\text { MIDDLE } & \text { UNMARKED } & \text { INTRANS. } & \text { TRANSITIVE } \\ \text { ba-h- } & \text { mu- } & \text { ba-s- } & \text { ba-t- }\end{array}$

and for standing, we have:

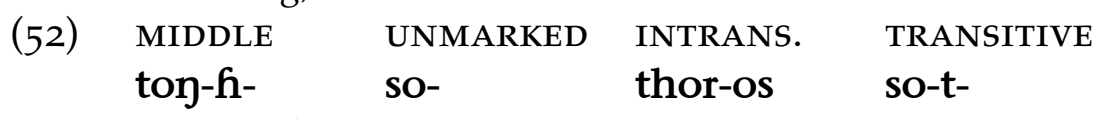

[Recall that so-fh- 'swell up' has a deviant meaning.] This is likely just a coincidence since similar patterns are not regularly found among other groups of nearly synonymous verbs, but it is a curious fact nonetheless.

Despite the fact that the VT stems are fully lexicalized, there is a high degree of predictability in their meanings given the sense of the root and meanings of the VT suffixes: stems marked with the transitive suffix $-(\mathbf{V}) \mathbf{t}$ - are unfailingly transitive and preserve the basic meaning of the stem very well. Similarly, those marked with the intransitive suffix -(V)s- are unfailingly intransitive and likewise preserve the basic meaning. The exceptions, not surprisingly, are the middles, which show the greatest degree of semantic drift: ba-h- 'settle down, alight' [from ba- 'sit'] and so-h- 'swell up' [from so'stand, rise'] have extended meanings, with the result that the latter has ceased to be a posture verb, though its relation to the other members of the so- stem set is still discernable. toy-h- 'be in a standing position' has the additional meaning 'stop' ${ }^{16}$ 
2.3.2. Expression of location: Unlike Chantyal, some posture verbs in Magar can be used to indicate location. In (53), we see intransitive ba-s- 'sit' used with an inanimate subject to indicate location:

khwa bhitr-an handa ba-s-le

small.clay.pot inside-LOC large.clay.pot sit-INTR-IMPF

'the khwa (small clay pot) sits inside the handa (large clay pot).' [T]

In (54), we find the causative of ba-s- used in a similar way:

(54)
ho-t-in
karan
ra-k-le,
D.DEM-PROX-ABL
moca liha tan-le,
ra ho-lak-an
banana leaf stretch-IMPF and D.DEM-CIR-LOC sit there.' [T]
kus-kat
kitab a-l-an
$m u-a$
which-one book R.DEM-CIR-LOC sit-PST
'which of the books over there stays?' [S]

kara- $\eta$

bamboo.basket bring-CAUS-IMPF

ba-s-ak

bamboo.basket-LOC

sit-INTR-CAUS put-IMPF

'afterwards we bring a bamboo basket, stretch a banana leaf over it and make it

Similarly, unmarked mu- 'sit' has evolved a sense meaning 'stay', which can be used to indicate location:

Verbs expressing the standing posture don't seem to be used to indicate location, however, locative expressions formed with the copular verb are used instead.

The expression of the lying posture is rendered by verbs whose basic sense means 'fall down'. These verbs can take animate or inanimate subjects, but are not used in the expression of location in ways analogous to English 'lie'.

2.3.3 Expression of manner: It is almost certainly an areal feature of the Tibeto-Burman languages of Nepal that they do not lexicalize posture + manner in ways analogous to English 'squat', 'crouch', 'lean', etc. As noted in section 1.3.4, Chantyal does not have verbs of this sort, and neither does Magar. In Magar, adverbial expressions of various sorts are used to supply information about manner.

(56) tokorok $\mathrm{mu}$ -

straight sit

'sit straight.' [S]

(57)

bha-t-alas mu-

separate-TR-ADV sit

'sit cross-legged.' [T]

Most likely, the fact that posture + manner is not lexicalized in Chantyal and Magar is related to the limited use of posture verbs in the expression of location - recall that posture expressions are not used idiomatically to express location in Chantyal, and only the verb ba- 'sit' has this use in Magar. In using a posture verb-based metaphor for the expression of location, a speaker is invoking an image suggesting the manner in which the subject is situated in space. By saying Milwaukee lies west of Lake Michigan, we create an image of the town arranged in space in a certain manner. Since these TibetoBurman languages rarely conflate verbal and manner senses into a single lexical item, 
they are less likely than languages that do this regularly, such as English, to use posture verbs for the expression of location.

2.3.3 Polysemy of basic posture expressions: In introducing the posture verbs in (40)(42), we noted the range of meanings that these verbs possessed. For the most part, these meaning extensions are familiar ones. Focusing here on expressions for sitting and standing, since it is only with these verbs that we have dedicated postural meanings, the following instances of polysemy were noted in (40) and (41):

$$
\begin{aligned}
& \text { mu-: SIT } \rightarrow \text { STAY } \\
& \text { ba-: SIT } \rightarrow \text { SETTLE DOWN, ALIGHT } \\
& \text { SO-: STAND / RISE } \rightarrow \text { SWELL UP } \\
& \text { SO-: STAND / RISE } \rightarrow \text { WAKE } \\
& \text { toy-: STAND } \rightarrow \text { STOP/WAIT }
\end{aligned}
$$

Note also that with so- and thor-, we have verbs which mean both 'stand' and 'rise'. Additional instances of meaning shift have been noted. For example, transitive ba-t- 'set down' can also mean, given the appropriate context, 'stop or 'desist' in an activity:

Bhim -e kajus-cə-ko-ke kajus-ke ba-t-ak-ke Manas-ke birhin-a Bhim-ERG work-ATT-PL-DAT work-NOM sit-TR-CAUS-NOM Manas-DAT sendPST

'Bhim sent Manas to make the workers stop their work.' [S]

The same verb compounded with mfluy 'tiredness' has the meaning 'rest':
hose-ko pahar-an kalh-a curcur-ay tak-dək-in
mhin-ba-t-a

D.DEM-PL rock.face-LOC climb-PST peak-LOC reach-COTEMP-ABL tire-sitTR-PST

'they climbed the rock face, and having reached the peak, they rested.' [S] mu- has extended its meaning beyond 'sit, stay' to 'live at/in':

$$
\text { hose mahja i-l-ay som lhes-in ho-ra mu-mo-le }
$$

D.DEM Woman P.DEM-CIR-LOC three year-ABL D.DEM-QUANT sit-NOM-IMPF

'that woman has lived here for three years.' [T]

$$
\text { hos-ko jum-cyo sah-an sahər-ay pu-le }{ }^{17}
$$

D.DEM-PL cold-ATT season-LOC city-LOC sit-IMPF

'they live in the city in the cold season.' [T]

$\mathrm{mu}$ - is also found in verb concatenation constructions, some of which have lexicalized meanings, as in the following example:
Ram-e kagat la-h-ak-ke
kagat-an me-cop mu la-a

Ram-ERG paper take-MID-CAUS-NOM paper-LOC POss-pitch sit take-PST

'Ram put pitch on the paper to cause the paper to stick together.' [S]

The verb concatenation mu la- means 'put on'.

2.4 Grammaticalization of posture expressions: It was noted in section 1.4, that the Chantyal copular verb mu derives from a verb meaning 'sit, stay'. Traces of its origins in a posture verb can be found in the fact that, in opposition to the other copular verb 
fin, $\mathrm{mu}$ is used in locational expressions as opposed to identificational ones, to which hin is now restricted.

As it turns out, Magar mu- 'sit, stay' is cognate with Chantyal mu. And just as with its Chantyal counterpart, Magar mu- has followed an evolutionary path toward purely grammatical meanings. The main grammatical use to which Magar mu- is put is in the expression of durative aspect. This use can be seen in the following three examples:

(64) hose mis-mə mu-me

D.DEM sleep-NOM sit-PRPF

'she is still sleeping. has been sleeping.' [T]

mi-ja-ja kur-hu-mə mu-le

POss-child-child fall-MID-NOM sit-IMPF

'the child is lying down.' [T]

(66) ka-yak babu-ja ra cyu mis-mə pu-nay rokotyak sisi-in

one-day boy-child and dog sleep-NOM sit-SIM frog bottle-ABL

bahire khyo-h-mo nu-a-an

outside emerge-MID-SEQ go-PST-LOC

'one day while the boy and the dog were sleeping, the frog came out from inside the bottle.' [T]

The semantic main verb is found in the form of a nominalization in the durative construction with $\mathbf{m u}$ - appearing as an auxiliary. The sense contributed by $\mathbf{m u}$ - in this construction is location within the time of the event, which derives from the 'stay, remain' senses that mu- has developed.

\section{Summary}

Despite the fact that Chantyal and Magar are related languages, have almost certainly been spoken in close proximity during the last few centuries, and are subject to the same areal influences [see Noonan 2001b], they show numerous differences in the ways in which posture verb expressions are formed and organized within the grammar. In sum:

- Chantyal makes extensive use of complex expressions in referring to posture, having only a small set of simplex verbs with posture senses. In contrast, Magar has a relatively large number of verbs referring to the sitting and standing postures: these verbs are formed by combining the verbal root with any of a number of voice/transitivity affixes.

- However, for the lying posture, both languages employ complex expressions or simplex verbs which refer to the lying posture only indirectly by inference: neither has dedicated verbs denoting this posture.

- Chantyal speakers must, on the one hand, distinguish between expressions which attribute agency to the subject and those which do not; and, on the other hand, distinguish between those which denote the assumption of a given posture and those which denote the maintenance of one. Neither distinction is made in Magar. 
- Neither language has simplex verbs which combine posture + manner.

- In Chantyal, expressions denoting posture are not used idiomatically to express location. In Magar, only one verb can be used idiomatically for the expression of location.

- In Chantyal, the few verbs with dedicated postural senses have not, with one exception, extended their meanings beyond postural senses. In contrast, postural verbs in Magar commonly exhibit extended meanings.

- In both languages, the verb mu- has acquired purely grammatical functions.

1 The work reported on in this paper has been supported by the following grants from the National Science Foundation: DBC-9121114, SBR-9600717, and SBR-9728369.

2 The figures given here are estimates, arrived at in consultation with ethnic Chantyals. In the last official census in 1991, the Chantyal were not an officially recognized ethnic group/caste and were not separately counted.

${ }^{3}$ See Noonan (1996) for a discussion of this question and for general ethnographic information, and Noonan (2001a) and Noonan et al (1999) and references given there for additional information about the Chantyal and their language.

4 The expressions in (2) can be used in reference to sitting, the 'vertical' sense contributed by tharo referring here to the spine and not the entire body. However, without supporting context, these expressions refer to standing.

${ }^{5}$ It should be noted that there is an additional set of expressions with ghowto 'prone' which can also translate English 'lie'.

(a) ghowto laghowto taghowto pəri-

'maintain a prone position' [literally: 'prone do']

'assume a prone position' [literally: 'prone become']

'come to be in a prone position' [literally: 'prone happen']

The expressions in (5) involving wattano 'supine' differ from those with gfowto 'prone' with reference to the orientation of the face; they also differ in that those with wattano strongly imply [but do not entail] that the subject is in a lying position, whereas those with gfowto do not and have a range of meanings which includes 'stoop', 'bend down', 'crouch down' as well as 'lie face down'. This difference between wattano and ghowto rests on the practical possibilities of human postures: to have one's face pointing upward and one's backside downward ['supine'] implies a lying posture, whereas having one's face pointing downward and one's backside up is a posture that can be easily achieved without lying down. It is for this reason that the expressions with wattano are included among the basic expressions for posture in Chantyal [and are the forms usually given by Chantyals as translations of English 'lie'], whereas those with gfowto are not included in the basic set.

${ }^{6}$ Chantyal exhibits the 'antidative' phenomenon: see Dryer (1986), Noonan (1991), and Noonan (2001a) for discussion.

${ }^{7}$ References in brackets, e.g. [R78] refer to numbered clauses in discourses published in Noonan et al (1999), Noonan \& Bhulanja (2001), and Noonan \& Bhulanja (in preparation).

${ }^{8} \mathrm{mu}$ is the unmarked copula and is occasionally found in identificational sentences, especially if a locative noun is present, as in He was a student in Kathmandu.

${ }^{9}$ The figures are reported in Gurung (1998).

${ }^{10}$ Among the reasons for this were the fact that Magars were officially unenslavable and the fact that they were one of the groups recruited by the British for enrollment in the Gurkha units of the British army. ${ }^{11}$ Most notable among these features is a more complex verb agreement system which resembles that of the Kiranti languages and consistent ergativity. 
12 Tanahu [T], Syangja [S], Gorkha [G], Rising [R], Yanchok [Y]. Data from the Yanchok Dialect are from Shepherd and Shepherd (1971, 1972, 1973). Data from the Rising Dialect are from Subba (1972). Transcriptions have been systematized. Data from the other Magar dialects and from Chantyal were collected by the authors.

${ }^{13}$ In parts of the Chantyal-speaking area, Chantyals and Magars share the same slopes, with the Chantyals living at the higher elevations and the Magars on the lower. However, in these Magars speak the national language, Nepali, and we know that they have spoken Nepali for a number of generations, perhaps as long as the Chantyal have inhabited the area they now share. See Noonan (1996) for a discussion of some of these issues. There appears to be, however, an early layer of Magar borrowings in Chantyal, which suggests that the two languages were once spoken in close proximity. Population movements have been frequent in Nepal and it is known that the Chantyals migrated to their current homeland within the last two centuries.

14 See Grunow-Hårsta (2002) for discussion.

15 -h- may represent phonetic murmur which extends over adjacent segments; it may also represent [h]. We choose to represent this morpheme by / $\mathrm{h} /$ so as not to confuse the morpheme with phonetic aspiration represented by $<\mathrm{h}>$.

${ }^{16}$ See Heine et al 1991 for discussion of the susceptibility of middles to meaning changes of this sort.

${ }^{17} \mathbf{~} \mathbf{u}$ - is a variant of $\mathbf{m u}$ - found in the Tanahu dialect.

\section{Abbreviations used in glosses}

$\begin{array}{llll}\text { ABL } & \text { ablative } & \text { MID } & \text { middle } \\ \text { ADES } & \text { adessive case } & \text { NOM } & \text { nominalizer } \\ \text { ADV } & \text { adverbial } & \text { NPST } & \text { non-past } \\ \text { ANT } & \text { anterior } & \text { P.DEM } & \text { proximal demonstrative } \\ \text { ATT } & \text { attributive } & \text { PERF } & \text { perfective } \\ \text { CAUS } & \text { causative } & \text { PL } & \text { plural } \\ \text { CIR } & \text { circumlative } & \text { POSS } & \text { inherent possession } \\ \text { COMP } & \text { comparative case } & \text { PPRF } & \text { past perfective } \\ \text { DAT } & \text { dative case } & \text { PRPF } & \text { present perfect } \\ \text { D.DEM } & \text { distal demonstrative } & \text { PROG } & \text { progressive converb } \\ \text { GEN } & \text { genitive } & \text { QUANT } & \text { quantifier particle } \\ \text { ERG } & \text { ergative case } & \text { R } & \text { Rising } \\ \text { ESS } & \text { essive case } & \text { R.DEM } & \text { remote demonstrative } \\ \text { FOCUS } & \text { focus/topic particle } & \text { S } & \text { Syangja } \\ \text { G } & \text { Gorkha } & \text { SEQ } & \text { sequential converb } \\ \text { GEN } & \text { genitive } & \text { SIM } & \text { simultaneous converb } \\ \text { IMPF } & \text { imperfective } & \text { SUPER } & \text { superessive case } \\ \text { INTR } & \text { intransitive } & \text { T } & \text { Tanahu } \\ \text { LOC } & \text { locative case } & \text { TR } & \text { transitive } \\ & & \text { Y } & \text { Yanchok }\end{array}$

Bibliography 
Benedict, Paul. 1972. Sino-Tibetan: a Conspectus. Princeton-Cambridge Studies in Chinese Linguistics, II. Cambridge (UK): Cambridge University Press.

Dryer, Matthew. 1986. 'Primary objects, secondary objects, and antidative.' Language 62/4:808-45.

Givón, Talmy. 1984. Syntax: A Functional-Typological Introduction. Amsterdam: John Benjamins.

Grunow-Hårsta, Karen. 2002. 'Magar'. In Carol Genetti \& Michael Noonan, eds. Five Languages of Nepal. Canberra: Pacific Linguistics.

Gurung, Harka. 1998. Nepal: Social Demography and Expressions. Kathmandu: New ERA.

Hale, Austin, ed. 1973. Clause, Sentence, and Discourse Patterns in Selected Languages of Nepal. Part III, Texts. Norman, OK: Summer Institute of Linguistics.

Heine, Bernd \& Ulrike Claudi, Fredericke Hünnemeyer. 1991. Grammaticalization: a Conceptual Framework. Chicago: Chicago University Press.

Hopper, Paul \& Sandra Thompson. 1980. 'Transitivity in grammar and discourse.' Langugage 52.2.

Noonan, Michael. 1991. 'Anti-dative shift.' Milwaukee Studies on Language 5:50-8.

Noonan, Michael. 1996. 'The fall and rise and fall of the Chantyal language.' Southwest Journal of Linguistics 15/1-2:121-36.

Noonan, Michael. 2001a. 'Chantyal', in The Sino-Tibetan Languages, Randy LaPolla and Graham Thurgood, eds. Richmond, England: Curzon Press.

Noonan, Michael. 2001b. 'Recent Language Contact in the Nepal Himalaya.' To appear in Himalayan Linguistics.

Noonan, Michael, with Ram Prasad Bhulanja, Jag Man Chhantyal, and William Pagliuca. 1999. Chantyal Dictionary and Texts. Berlin: Mouton de Gruyter.

Noonan, Michael, with Ram Prasad Bhulanja. 2001. Chantyal Texts. In Himalayan Linguistics, ed. by George van Driem. Berlin: Mouton de Gruyter.

Noonan, Michael, with Ram Prasad Bhulanja. In preparation. Chantyal Grammar.

Shepherd, Gary \& Barbara Shepherd. 1971. 'Magar phonemic summary.' Kirtipur: SIL. mineo.

Shepherd, Gary \& Barbara Shepherd. 1972. 'A vocabulary of the Magar language.' Kirtipur: SIL. mineo.

Shepherd and Shepherd. 1973. 'Magar texts'. In Hale 1973.

Subba, Subhadra. 1972. A Descriptive Analysis of Magar: A Tibeto-Burman Language. University of Poona PhD dissertation. 
Figure 1: Proposed Genetic Relationships Within the Bodic Section of Tibeto-Burman

[names of languages included within the present paper are in italics]

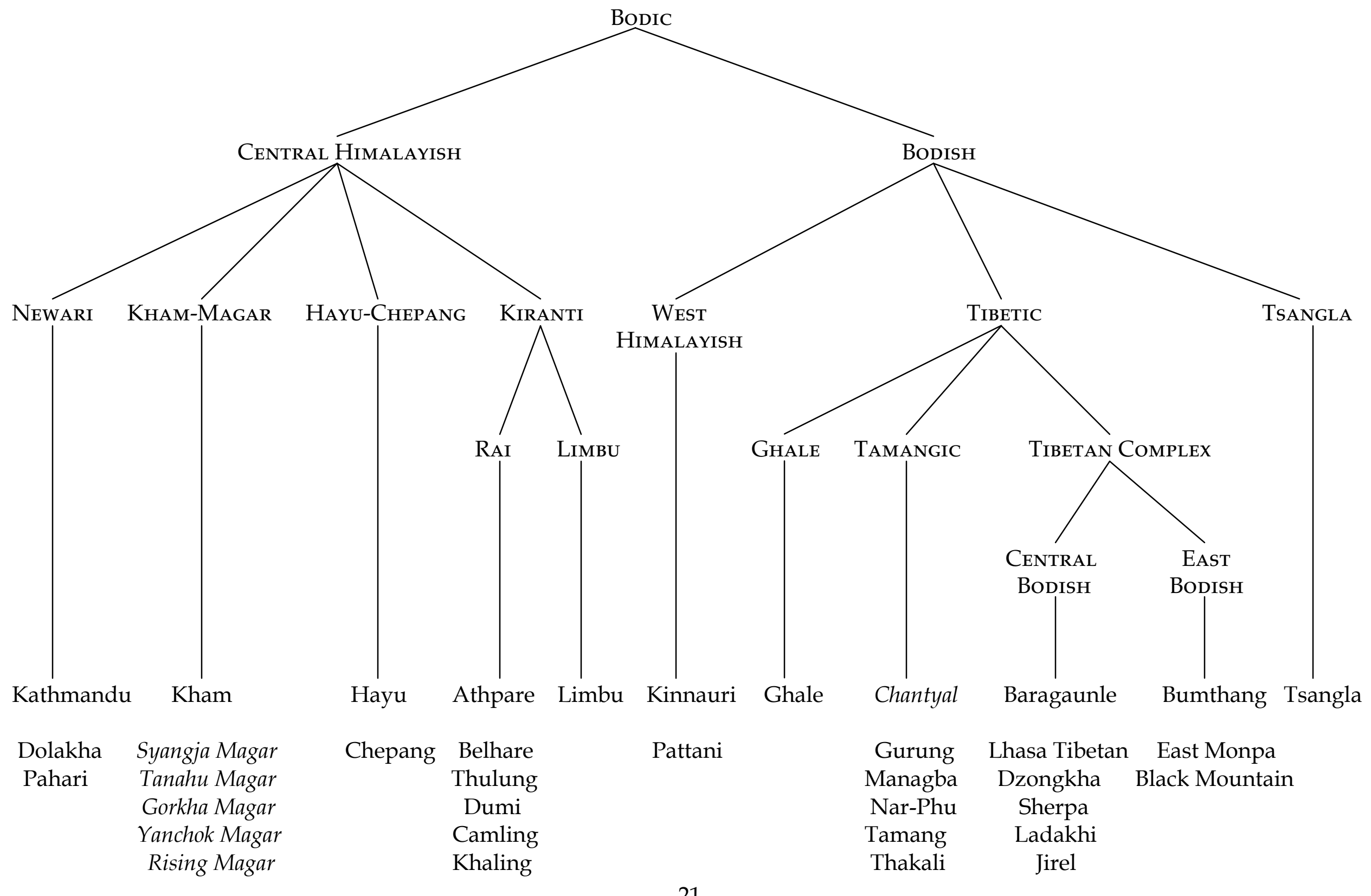


